\title{
Evaluation of the power of six clustering features in identifying a homogeneous disease subset in juvenile idiopathic arthritis (JIA) A Magnani*1, S Oliveira ${ }^{2}$, E Castell ${ }^{5}$, O Arguedas ${ }^{4}$, N Ullmann ${ }^{1}$, S Pederzoli ${ }^{1}$, S Magni Manzoni ${ }^{3}$, A Pistorio ${ }^{1}$, N Ruperto ${ }^{1}$, A Martini $^{1}$ and A Ravelli ${ }^{1}$
}

\author{
Address: ${ }^{1}$ IRCCS G Gaslini, Genova, Italy, ${ }^{2}$ Universidade Federal do Rio de Janeiro, Rio de Janeiro, Brazil, ${ }^{3}$ IRCCS Pol San Matteo, Pavia, Italy, \\ ${ }^{4}$ Hospital Nacional de Ninos Herrera, San Josè, Costa Rica and ${ }^{5}$ Hospital General de Ninos P. Elizalde, Buenos Aires, Argentina \\ * Corresponding author
}

\author{
from 15th Paediatric Rheumatology European Society (PreS) Congress \\ London, UK. 14-17 September 2008 \\ Published: 15 September 2008 \\ Pediatric Rheumatology 2008, 6(Suppl I):P55 doi:I0.II86/I546-0096-6-SI-P55
}

This abstract is available from: http://www.ped-rheum.com/content/6/SI/P55

(c) 2008 Magnani et al; licensee BioMed Central Ltd.

\section{Background}

The ILAR classification of JIA represents a work in progress. It has been suggested that patients with clustering features of early onset, female prevalence, asymmetric arthritis, positive ANA, and risk of iridocyclitis constitute a homogeneous entity, irrespective of the course of joint disease.

\section{Objective}

To compare power of each clustering feature in identifying a homogeneous disease subgroup in JIA.

\section{Methods}

All patients seen in study centers between 1983 and 2004 $(\mathrm{N}=750)$ were classified according to ILAR criteria. Categories of systemic arthritis, RF-positive polyarthritis, and enthesitis related arthritis were excluded because it was felt they represent sufficiently homogeneous entities. Patients in the remaining categories (oligoarthritis persistent and extended, RF-negative polyarthritis, psoriatic arthritis and undifferentiated arthritis) were grouped together $(\mathrm{N}=603)$. In each patient, the presence of the 6 clustering features was assessed. The relative power of each clustering feature in identifying a homogeneous disease subgroup was examined by assessing its ability to separate patients by the presence of the remaining clustering features.

\section{Results}

The ANA revealed the greatest power in separating patients with or without the other clustering features (see table 1), $\mathrm{p}<0.01$.

\section{Conclusion}

The ANA status revealed the strongest ability in identifying the disease subgroup characterized by the presence of clustering features. The optimal threshold for ANA positivity needs to be defined. 
Table I:

\begin{tabular}{lll}
\hline & ANA Pos & ANA Neg \\
\hline Mean onset age (years) & 3.9 & 6.8 \\
Patients with onset age < 6 years (\%) & 81.3 & 45.9 \\
Females (\%) & 80.0 & 68.8 \\
Asymmetric arthritis at 6 months (\%) & 78.4 & 63.2 \\
Iridocyclitis (\%) & 25.4 & 1.9 \\
\hline
\end{tabular}

Publish with Bio Med Central and every scientist can read your work free of charge

"BioMed Central will be the most significant development for disseminating the results of biomedical research in our lifetime. " Sir Paul Nurse, Cancer Research UK

Your research papers will be:

- available free of charge to the entire biomedical community

- peer reviewed and published immediately upon acceptance

- cited in PubMed and archived on PubMed Central

- yours - you keep the copyright

Submit your manuscript here:

http://www.biomedcentral.com/info/publishing_adv.asp 